\title{
Environmental health risk from past uranium mining and milling activities
}

\author{
F. P. Carvalho \\ Instituto Tecnológico e Nuclear, Departamento de Protecção \\ Radiológica e Segurança Nuclear, Portugal
}

\begin{abstract}
In the last few years several European countries undertook closure and environmental remediation of old uranium mining sites. This is the case for Portugal. Due to concerns about public health, environmental radioactivity was recently investigated in a number of counties in the Centre-North of Portugal where the extraction and chemical treatment of uranium ore was carried out, as well as in reference areas. The results of this environmental research and of an assessment of the health condition of local populations allowed the conclusion that some exposure to radioactivity from uranium mining waste occurs in these areas. The reduction of such exposure should be achieved through environmental remediation measures. However, as radio nuclides in uranium mining and milling waste are very long lived and their potential to cause health hazards will last for centuries, remediation measures should be effective for generations. To achieve this goal adequate radioactivity monitoring around sites is needed and institutional custody of waste repository sites should be ensured.
\end{abstract}

Keywords: uranium mining, radioactive waste, ionizing radiation effects, public health, environmental remediation.

\section{Introduction}

Mining of radioactive ores in European countries took place during most of the last century. With the opening of very large uranium mines in Australia, Canada and Africa, uranium mining activities were displaced to these regions and former radium-uranium European producing countries closed their mines and radioactive ore treatment plants by the turn of the century. Since then, these countries started environmental remediation of former uranium mining and 
milling facilities. This occurred in France, East Germany, Spain, and in Portugal as well [1]. Growing environmental concerns and recommendations developed by international organisms for enhanced measures in the field of radiological protection of workers and members of the public, such as the Basic Safety Standards developed by the International Atomic Energy Agency [2] and the Basic Safety Standards approved by the European Union [3], fostered environmental remediation in former uranium mining areas and provided a technical framework for remediation goals.

In the beginning of uranium mining activity there was no awareness of ionizing radiation risks and environmental protection measures were less strict than they are today. In the present, the legacy of large uranium mining and milling waste deposits raises concerns about the risk of exposure of man through environmental pathways. Today, most of former uranium producing countries must deal with this legacy. These mining and milling wastes contain high concentrations of long lived radio nuclides, such as radium $\left({ }^{226} \mathrm{Ra}\right)$ with a halflife of 1600 years. Therefore, on one hand, environmental remediation measures shall be effective for long time in preventing the environmental contamination and exposure of populations to radioactivity. On the other hand, with the rising price of uranium, some countries may re start uranium mining and, thus, lessons from previous time must be taken into account in future activities.

This paper gives an account of the radium and uranium mining industry in Portugal, of waste generated and environmental radioactivity enhancement in old mining areas as well as of exposure of populations. Lessons to be retained are discussed.

\section{Uranium mining industry in Portugal}

Radioactive ores were exploited in Portugal during most of the last century. In total 61 mines mostly located in the uraniferous region at centre-North of the country (Fig. 1), were exploited as open pits or underground mines or in a combination of both methods.

For radium production the ores were chemically treated in the Uranium Salts Factory (1909-1926) located in Barracão, near Guarda. Later, for uranium production, ores from small mines were sent to one of the main facilities for uranium extraction. The largest mill and chemical treatment plant operated (1951-2001) at the Urgeiriça mine, in Canas de Senhorim, near the city of Viseu (Fig 1). These facilities ceased activity in 2001 and are now in the decommissioning process.

During the decades of radium-uranium mining, 50 - 100 grams of radium and 4370 tons of uranium oxide $\left(\mathrm{U}_{3} \mathrm{O}_{8}\right)$ were produced. This activity generated solid wastes amounting to about 13 million tons including low radioactivity barren rocks, sands from extracted ores, and sludge from acid mine water treatment. From this total, near 3 million tons are located in the facilities of Urgeiriça mine, in low grade ore heaps (not extracted), milling tailings, and sludge ponds. Other waste heaps are deposited near other uranium mines in the region, such as Cunha Baixa, Quinta do Bispo and Bica [4]. 


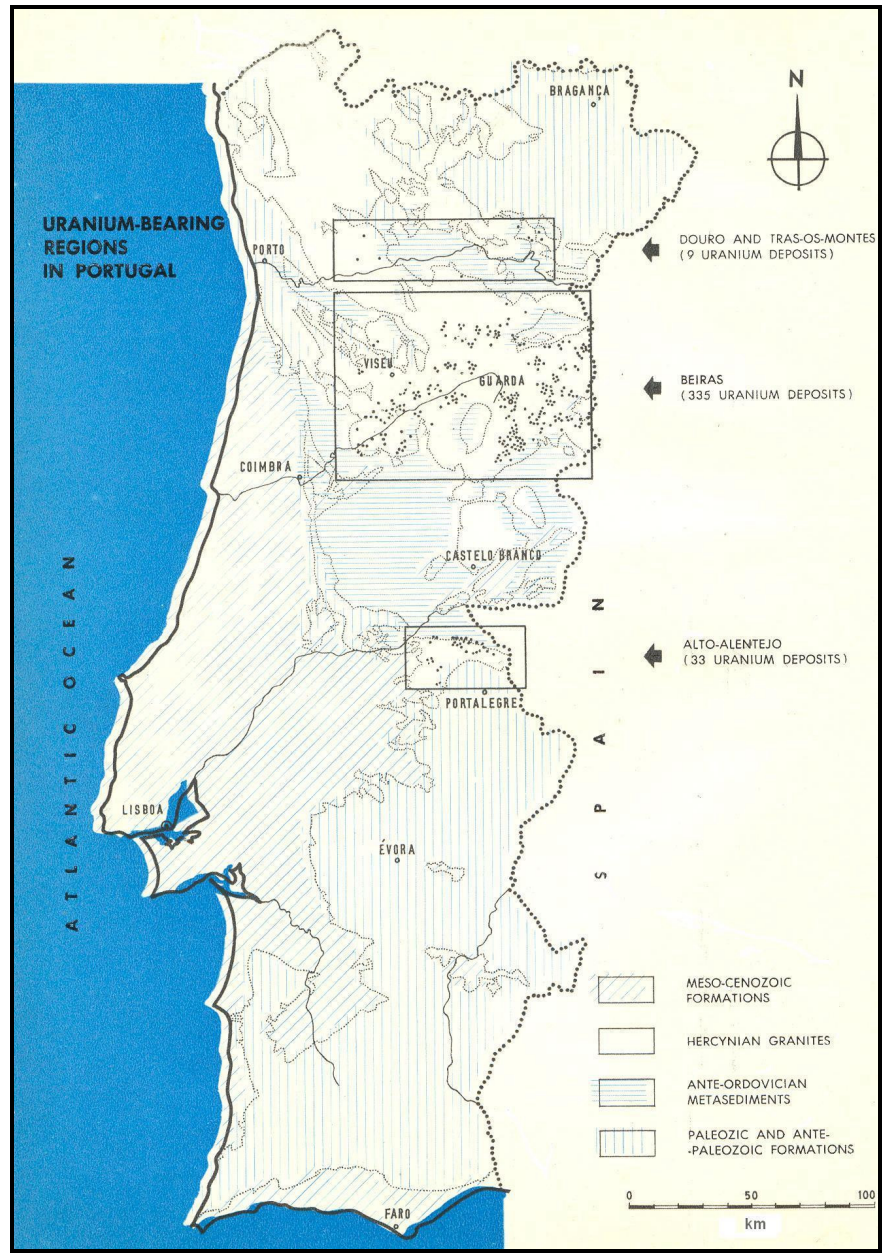

Figure 1: Location of the main uranium deposits in Portugal in a historic map (Source: JEN, 1969).

At the Urgeiriça mine site, liquid effluents from ore processing, surface runoff and drainage from the mill tailings have been released into a creek, Ribeira da Pantanha, flowing into the Mondego River, a major hydrographic basin in the region, causing some dispersal of radio nuclides in the environment [5]. During decades of mining activity, the U mining company has controlled the area and restricted the access to the waste tailings, thus minimizing the spread of contaminated materials in the region. Sulfuric acid was used in this underground mine for in situ uranium extraction. This procedure generated acid waters that infiltrate into groundwater. 
Human activities may have contributed to enhance environmental radioactivity levels in the surrounding areas, for example through dispersal of materials recuperated from mining waste, such as sands and gravel used in improving rural roads and in construction. Further contributions might have come from wind erosion and radon emanation from tailings. This enhancement of environmental radioactivity levels may have caused exposure of populations to ionizing radiation above the natural background levels.

\section{Assessment of environmental radioactivity}

An assessment of environmental radioactivity was carried out in the county of Canas de Senhorim, Urgeiriça mine (Zone A), where U mining and milling wastes are accumulated in larger amounts than elsewhere. This assessment was extended to other counties with old uranium mines (Zone B) and also to counties with no past uranium mining (Zone $\mathrm{C}$ ) in order to use the last ones as a reference area. All are located in the same geologic region.

The ambient radiation dose measured in Canas de Senhorim, outside the mining areas, averaged $2.5 \mathrm{mSv} \mathrm{a}^{-1}$. Within the statistical uncertainty, this value compares to doses determined in counties with no uranium mining activities and no residues (Table 1). However, measurements made in the county of Canas de Senhorim but inside areas affected by the uranium mining activities, showed elevated radiation doses. These doses may reach for instance $41.2 \mathrm{mSv}^{-1}$ at the ore discharge in the milling facility.

It is interesting to observe the differences in radiation doses determined on two tailings, "Barragem Velha" and "Barragem Nova", existing in the area. While on "Barragem Velha" (dumpsite for extracted ore) the ambient dose amounts to $18.6 \mathrm{mSv} \mathrm{a}^{-1}$, on "Barragem Nova" (dumpsite for sludge from mine water treatment) the dose is much lower, $3.4 \mathrm{mSv}^{-1}$ (Table 1). The reason for the difference was clarified through spectrometric analysis of waste materials and relates to the origin of waste. Milling waste (deposited in "Barragem Velha") corresponds to sandy materials rejected after uranium extraction and contains low concentrations of uranium and high concentrations of uranium descendants, such as ${ }^{230} \mathrm{Th},{ }^{226} \mathrm{Ra},{ }^{210} \mathrm{~Pb}$ and ${ }^{210} \mathrm{Po}$. Sludge from acid mine water treatment (accumulated in "Barragem Nova") has a different composition and displays uranium activity concentrations much higher than those of $U$ descendants delivering lower gamma dose rate (Table 2).

As tailings are exposed to weathering, surface runoff may transport radio nuclides in the particulate phase, as well as rainwater seepage may transport dissolved radio nuclides into the surface water streams and sub-surface water reservoirs. Concentrations measured in surface drainage (BV1) and water percolated through the tailings (BV2) collected at "Barragem Velha" were very high for dissolved uranium and confirmed the role of these transport pathways. Acid water from the underground mine of Urgeiriça displays also very high radionuclide concentrations that may exceed concentrations in uncontaminated surface waters of Ribeira da Pantanha by three orders of magnitude (Table 2) $[5,6]$. 
Analysis of radionuclides in agriculture soils has shown enhanced concentrations in soils in the vicinity of mining and milling areas. This was the case in the county of Canas de Senhorim, for instance. Nevertheless, apart the area of mining facilities soils do have naturally-occurring radionuclide concentrations comparable to soils in reference counties.

Table 1: Environmental annual dose equivalent, in $\mathrm{mSv}[6]$.

\begin{tabular}{llcc}
\hline Zone & Site & $\begin{array}{c}\text { Arithmetic mean } \\
\left(\mathbf{m S v ~ a}^{-\mathbf{1}}\right)\end{array}$ & $\begin{array}{c}\text { Geometric mean } \\
\left(\mathbf{m S v ~ a} \mathbf{~}^{-1}\right)\end{array}$ \\
\hline $\mathbf{A}$ & $\begin{array}{l}\text { Canas de Senhorim (a) } \\
\text { outside mining } \\
\text { concession }\end{array}$ & $2.5 \pm 0.8$ & $2.4 \pm 0.1$ \\
& $\begin{array}{l}\text { Tailing Barragem Velha } \\
\text { (b) }\end{array}$ & $18.6 \pm 27.6$ & $8.8 \pm 1.8$ \\
& $\begin{array}{l}\text { Tailing Barragem Nova } \\
\text { (b) }\end{array}$ & $3.4 \pm 1.4$ & $3.2 \pm 0.3$ \\
& $\begin{array}{l}\text { Ore discharge at mill } \\
\text { station (b) }\end{array}$ & $41.2 \pm 27.9$ & $32.0 \pm 11.0$ \\
\hline B & Moreira de Rei & $2.2 \pm 0.4$ & $2.2 \pm 0.1$ \\
& Rio de Mel & $2.3 \pm 0.5$ & $2.3 \pm 0.1$ \\
\hline C & Sátão & $1.3 \pm 0.3$ & $1.23 \pm 0.04$ \\
\hline
\end{tabular}

(a) Without the mining areas; (b) Mining areas and contiguous land.

The results indicate that dispersion of solid radioactive wastes from Urgeiriça mining facilities did occur into adjacent soils and into river basins in the region to some extent. Enhanced radioactivity levels were measured also in water from wells in this area and in other old mining areas. Although generally not used as drinking water supply anymore, wells still are currently used as irrigation water source. Measurements of radon and aerosols in surface air have shown enhanced concentrations also of radio nuclides in the atmosphere of the region.

Altogether these enhanced concentrations of uranium daughters in the environment increased the exposure of local inhabitants to ionizing radiation. It was concluded that the urgent issues are to confine residues, preventing further waste dispersal in the environment, and to protect the water lines from discharges of contaminated leaching and surface runoff from tailings. Otherwise radioactivity will spread further and human exposure to ionizing radiation may increase.

\section{Effects on population health}

The effects of exposure to environmental radioactivity from past uranium mining activities on populations' health were evaluated in two ways. One, through statistical tests on differences of biological parameters measured in the population of Canas de Senhorim (A) and in the populations used as a 
comparison term $(\mathrm{B}+\mathrm{C})$. The other, through looking at indicators of internal accumulation of radio nuclides and genetic damage induced in chromosomes by radiation.

Table 2: Concentration of alpha emitting radio nuclides $\left(\mathrm{Bq} \mathrm{kg}^{-1} \pm 1 \sigma\right)$ in samples from mining and milling tailings at the Urgeiriça mine [5].

\begin{tabular}{|c|c|c|c|c|}
\hline & ${ }^{238} \mathbf{U}$ & ${ }^{230} \mathrm{Th}$ & ${ }^{226} \mathrm{Ra}$ & ${ }^{210} \mathrm{Po}$ \\
\hline \multicolumn{5}{|l|}{ Uranium tailings } \\
\hline BV- Barragem Velha & $2530 \pm 94$ & $10337 \pm 598$ & $24717 \pm 2039$ & $20354 \pm 681$ \\
\hline BN- Barragem Nova & $41598 \pm 1228$ & $13390 \pm 613$ & $1690 \pm 150$ & $1176 \pm 43$ \\
\hline MS- Milling station & $38316 \pm 1154$ & $30115 \pm 1123$ & $15569 \pm 707$ & $30824 \pm 1147$ \\
\hline \multicolumn{5}{|l|}{$\begin{array}{l}\text { Acid mine water } \\
\text { (Urgeiriça mine) }\end{array}$} \\
\hline $\begin{array}{l}\text { Filtered water } \\
(-20 \mathrm{~m})\end{array}$ & $2.17 \pm 0.07$ & $0.015 \pm 0.003$ & $1.48 \pm 0.06$ & $0.146 \pm 0.004$ \\
\hline $\begin{array}{l}\text { Suspended matter } \\
(-20 \mathrm{~m})\end{array}$ & $(35.1 \pm 1.7) \times 10^{3}$ & $(1.8 \pm 0.1) \times 10^{3}$ & $(12.1 \pm 0.5) \times 10^{3}$ & $(52.5 \pm 2.8) \times 10^{3}$ \\
\hline \multicolumn{5}{|l|}{ Runoff from tailings } \\
\hline $\begin{array}{l}\text { BV1- Surface runoff } \\
\text { (Dissolved) }\end{array}$ & $13.2 \pm 0.6$ & $1.17 \pm 0.08$ & $0.672 \pm 0.06$ & $0.69 \pm 0.03$ \\
\hline $\begin{array}{l}\text { BV2- Percolation } \\
\text { water (Dissolved) }\end{array}$ & $35.7 \pm 1.1$ & $1.06 \pm 0.06$ & $1.84 \pm 0.03$ & $0.70 \pm 0.04$ \\
\hline
\end{tabular}

Analyses of bio-medical parameters in populations confirmed that

- population A displays results compatible with a reduced performance of several biological functions in comparison with $\mathrm{B}+\mathrm{C}$ populations,

- this reduction in performance was more clearly observed in the male reproductive health, thyroid function and blood cell counts,

- concentrations of lead, copper, and zinc in blood serum were also higher in A,

- although less significant, results suggest also a reduction of the woman's reproductive health and of the kidney function in $\mathrm{A}$.

Notwithstanding, the observation method used in this study does not allow to identify the causes for the health differences measured in these population groups. However, the long term exposure of A population to radio nuclides and heavy metals from uranium mining is the most plausible cause for the differences measured [6].

Additional studies were carried out to assess the exposure of populations to radio nuclides. These were performed through analysis of radio nuclides in human hair and analysis of chromosome aberration in lymphocytes from peripheral blood. Analyses of ${ }^{210} \mathrm{Po}$ and ${ }^{210} \mathrm{~Pb}$ in human hair have shown that the population living near the mining and milling tailings eliminates more ${ }^{210} \mathrm{Po}$ in the hair than reference groups [7]. This implies that the body burden of this 
population group in ${ }^{210} \mathrm{Po}$ parent radio nuclides, i.e., ${ }^{226} \mathrm{Ra}$ and ${ }^{210} \mathrm{~Pb}$, is higher than in the reference population. Furthermore, the genetic analyses indicated that the exposed population may have slightly higher chromosome aberrations that non exposed groups, and do have more efficient repair mechanisms for induced genetic lesions than the reference group which implies a previous exposure to ionizing radiation [6].

This investigation on exposure and effects on humans confirmed that environmental radioactivity and toxic metals from uranium mining waste, although relatively confined in space, have exposed local populations through environmental transfer pathways. These findings underscored the need to carry out environmental remediation and to monitor the environmental radioactivity and food chain transfer of radio nuclides in these areas.

\section{Environmental remediation}

Environmental remediation of the old mining areas was decided by the Government [8]. Remediation plans foresee the disposal of solid waste in the main open pits of each mining area, five in total. The tailings of Urgeiriça will be reshaped and capped in the same place where they have been located for decades, after cleaning the area of the chemical treatment plant and adding these residues to the dump site. Capping the waste dump will be performed with geotextile membrane and soil from the region. The underground mine will be flooded and the acid water monitored as well as the leaching from the tailings.

The closure of waste disposal sites requires radioactivity surveillance for some time after completion of the remediation intervention. This surveillance should assess the exposure of populations through ingestion of local agriculture products, water, and aerosols inhalation. This surveillance should be carried out for compliance also with Euratom treaty Art. 35.

\section{Future radiological risks and stewardship of sites}

Environmental remediation is expected to immediately reduce ambient radiation doses. Furthermore, capping must also reduce radon emanation from tailings into the atmosphere, and thus will contribute to abate irradiation of lungs through inhalation. Nevertheless, the weathering of waste dumps will continue through decades and centuries and, thus, maintenance of the sites must be foreseen in order to prevent removal (erosion, intrusion, etc.) of capping materials. Water may flow through the waste and generate radioactive leaching that eventually could reach groundwater. These risks require a periodic monitoring of radioactivity in the environment and corrective measures as needed.

Stewardship of remediated sites is needed but costs may vary according to the engineered solutions. Solutions based on active treatment of effluents and sophisticated maintenance will be costly and subject to undue interruption in the future and, therefore, seem too much contingent to last for generations. May be a better choice would be the adoption of natural remediation processes, requiring minimal maintenance. 
Past uranium mining activities were justified and profitable. In the present, the mining and milling waste accumulated desirably should be out of the biosphere in order to prevent radiological exposure of man. This has to be achieved in old uranium mining areas and requires environmental remediation and radiological surveillance for the next decades to ensure that waste disposal methods are protecting the public health in an effective manner.

\section{References}

[1] M. Hagen, A.T. Jakubick (2006). Returning the WISMUT legacy into productive use. In: Uranium in the Environment: Mining Impacts and Consequences, pp 11-26. B.J. Merkel and A. Hasche-Berger (Ed.). SpringerVerlag, Berlin Heidelberg.

[2] International Basic Safety Standards for Protection against Ionizing Radiation and for the Safety of Radiation Sources. Safety Series No 115. International atomic Energy Agency, Vienna, 1996.

[3] European Union Directive 96/29/EURATOM.

[4] F.P.Carvalho, M.J. Madruga, M.C. Reis, J.G. Alves, J.M. Oliveira, J. Gouveia, L. Silva (2005). Radioactive survey in former uranium mining areas in Portugal. Proceed. of an International Workshop on Environmental Contamination from Uranium Production Facilities and Remediation Measures, held in Lisbon 11-13 Feb 2004, pp.29-40. International Atomic Energy Agency, Vienna.

[5] F.P.Carvalho, J.M.Oliveira, M.J.Madruga, I.Lopes, A.Libanio, L.Machado (2005). Contamination of hydrographical basins in uranium mining areas of Portugal. In: Uranium in the Environment: Mining Impacts and Consequences, pp 691-702. B.J. Merkel and A. Hasche-Berger Ed. SpringerVerlag, Berlin Heidelberg.

[6] J.M. Falcão, F.P. Carvalho, M.M. Leite, M. Alarcão, E.Cordeiro, J. Ribeiro, et al. (2005). MinUrar-Minas de Uranio e seus Resíduos.Efeitos na Saúde da População. Relatório Científico I (Julho de 2005). Publ. INSA, INETI, ITN.(available from www.itn.pt)

[7] F. P. Carvalho and J. M. Oliveira (2006). Natural radioisotopes ${ }^{210}$ Po and ${ }^{210} \mathrm{~Pb}$ in human hair as an indicator of exposure. In: Metal Ions in Biology and Medicine, Vol 9, pp.570-576. M Alpoim and P. Collery Ed., J. Libbey Eurotext Publishers, Paris.

[8] Santiago Baptista A. (2005). The programme for remediation of contaminated sites: its regulation and follow-up in Portugal. Proceed. of an International Workshop on Environmental Contamination from Uranium Production Facilities and Remediation Measures, held in Lisbon 11-13 Feb 2004, pp.223-232. International Atomic Energy Agency, Vienna. 